\title{
Sleep Concerns and Disorders in Children with an Autistic Spectrum Disorder (ASD)
}

\author{
Oreste Battisti \\ Faculty of Medicine, University of Liège, \\ Belgium
}

\section{Introduction}

The autistic spectrum disorder or ASD is frequently described or defined from several common characteristics during the periods of time concerning the wake time. More than many other situations, the investigations in ASD are difficult due to the particular personality encountered in this entity. This paper aims to present the interest of sleeping time study, owing to our experience and studies concerning sleep concerns in infants born prematurely, and in children suffering an ASD.

\section{Definition of the autistic spectrum disorder or ASD and historical note}

The ASD is included in the pervasive developmental disorders in the fourth edition text revision or DSM-IV-TR. That means that the original clinical description (Kanner's classic autism) has hardly changed with time, owing to the great variability of form and intensity in presentation. This clinical and biological entity contains a group of disorders (see Table I) with impairments in three major aspects: socialization, communication and behavior. It represents different clinical forms having however common social difficulties: a delay in language skills, an impaired social interaction, an impaired verbal or non-verbal communication, and repetitive, stereotyped or severely restricted activities and interests.

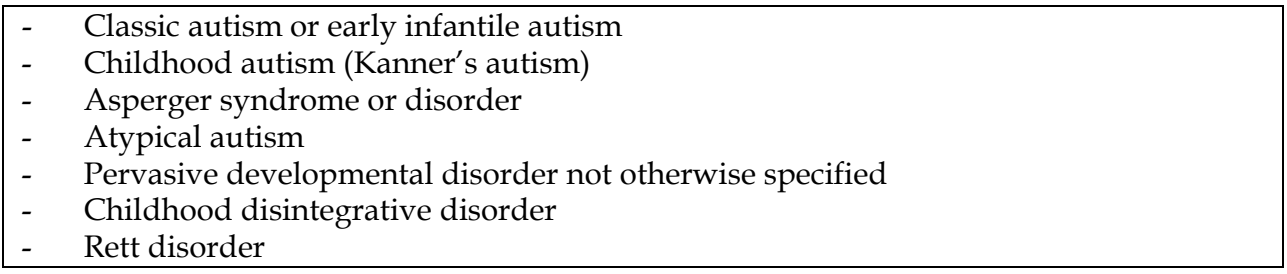

Table 1. The different forms of ASD

\section{Diagnosis}

It might happen, in most typical cases and with a short video recording, that the diagnosis is rapidly done. In most cases however, it will need time, after several observations and records of the CHAT or ADOS scales. One needs also to exclude the intervention of a mental 
retardation, an epilepsy, the effects of psychotropic drugs. The first signs may become prominent during infancy, and the diagnosis is merely done at three years, eventually sooner or later in life. In case of suspicion, it is highly recommended to address the infant to a specialized multidisciplinary team, after also an establishment of the IQ, a neuropsychological assessment, the assessment of hearing and vision .

\section{Epidemiology, etiology, clinical description of ASD}

The prevalence of ASD at 8 years of age has increased from 0.4 to about 2/1000 (range: 2-9 /1000. This observations is due to a combination of changes in case definition and an increased awareness together with more specialized developmental services. There is a male predominance with a male:female ratio of $4: 1$. One can also mention that ASD is present in siblings of an established ASD, in 2-8 percent. ASD is more frequently encountered in cases of monozygot twins and in case of prematurity. Associated following conditions are possibly found:

- Mental retardation;

- Seizures;

- Brain and cerebellum abnormalities (importance of MRI studies);

- Fetal alcohol syndrome;

- Phenylketonuria;

- Tuberous sclerosis;

- Chromosomal abdnormalities: Fragile X, Rett syndrome, Angelman syndrome, 15 q long arm duplication/triplication.

The causes or explanations of this entity are no yet elucidated, even if both genetics and environment seem to play a role in 10 to $25 \%$ cases. It is likely that interactions between multiple genes (locus on chromosomes 15 and 16) are responsible, and that epigenetic factors and exposure to environmental modifiers contribute to the variable expression. Several biochemical abnormalities such as an impairment of intra cerebral folic acid, serotonine, catecholamines and the opiod systems have already been reported. Several studies concerning the outside and inside receptors to different neurotransmitters are in progress. Until now, the association with immunizations (mainly thimerosal as conservative) is not confirmed.

\section{The building of a normal sleep architecture in infants}

Before 6 months of age, in normal circumstances, the infant falls in sleep and goes directly in a REM or rapid eye movement phase and remains in it during about 55 minutes. REM phase is followed by a non REM phase which remains about 65 minutes. After 6 months of age, the infant falls in sleep and goes directly in a non REM phase, remains in it for about minutes 90-120 minutes, and it is followed by a REM phase for a period of about 45 minutes. A sleep cycle contains a REM and non REM phase. Sleeping night time contains 8 cycles until 12 months, 6 cycles from 12 to 24 months, and 5 cycles after this age. The repartition of all these cycle has an homogenous distribution through night before the 24 months of age, and more --distributed after midnight after this age. These facts are illustrated in the Figure 1.

It is known that this process is in correlation with the melatonin synthesis from tryptophan in the infant. We can summarize that physiology by the following points:

- Circadian rhythm is usually present between 3 to 6 months of age; 
- $\quad$ The sun and the melatonin synthesis have an important role;

- The secretion (by the pineal gland) of melatonin becomes evident at 3 months of age, and it increases until 1 year of age, and thereafter remains stable until puberty;

- Its secretion and release shows an increasing level at around 7-8 pm, with a pic level at 2-3 am, an remains stable from 7 am until 7-8 pm;

- One can observe a significantly low level in case of epilepsy, ASD, diabetes, babies born before 32 weeks or with a birth weight below $1500 \mathrm{~g}$ and in babies born from addicted mothers.

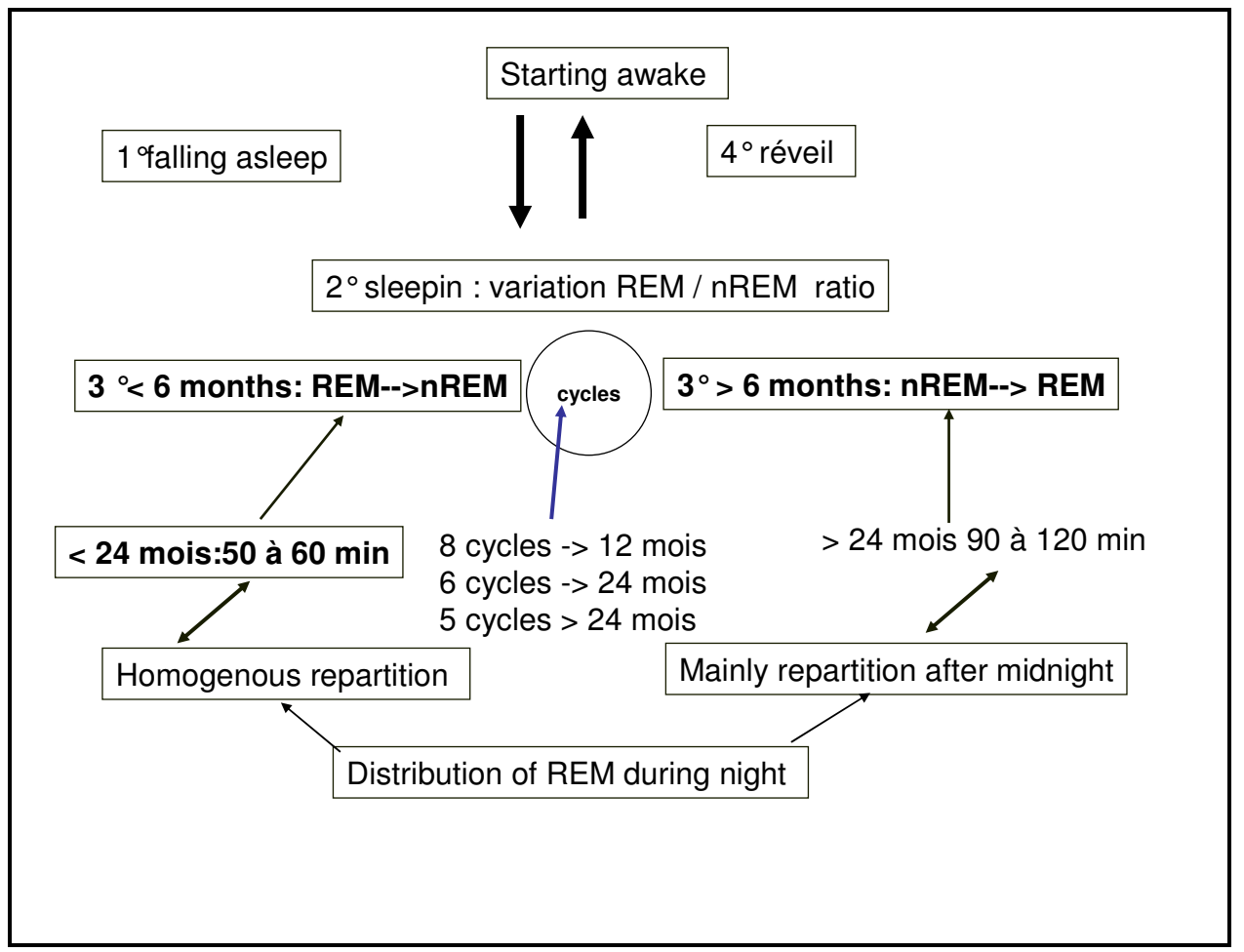

Fig. 1. The building of the normal sleep architecture in humans.

\section{Sleep concerns in the autistic spectrum}

In the ASD, the prevalence of sleep problems is between 44 and $83 \%$ (in comparison of $30 \%$ found in other population). It is not correlated to the IQ, although the degree of mental retardation tends to predict sleep impairment. Sleep disorders are hence more frequently encountered in children with an autistic spectrum.

The sleep disorders are not universal in autism, but they concerns about $55 \%$ of these beings. Good sleepers with ASD have fewer affective problems and satisfying social interactions.

Sleep disorders in ASD are listed in Table II. 


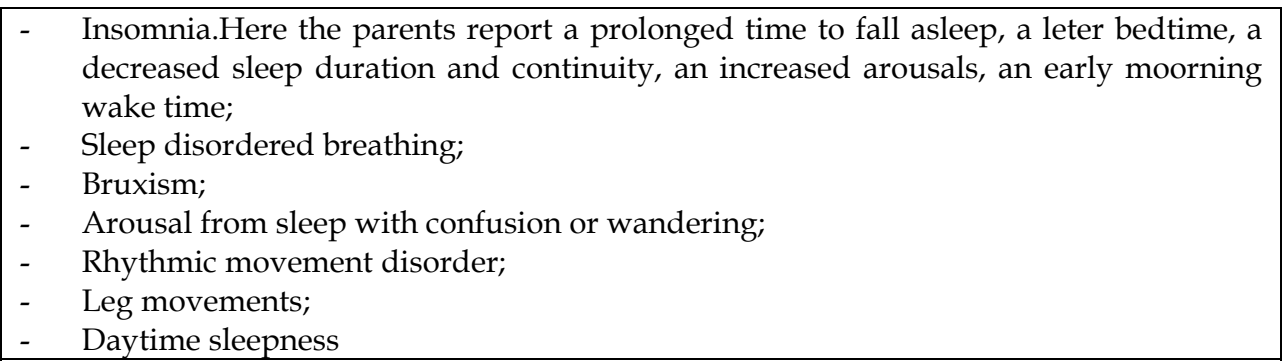

The most frequently encountered sleep disorder in ASD is insomnia;

One can understand that the expected building of normal sleep architecture (see above) is not easily encountered in ASD.

The sleep studies (polysomnography or better hypnology) in infants having sleep problems early in life are mainly indicated in situations concerned by the risk of cot death and the suspicion of epilepsy. Studies concerning behavioral difficulties in infants or children are not so few.

\section{Observations in sleeping times of children having a ASD}

In a group of 22 children with an ASD aged between 4 and 8 years, we find the following observations in a global polysomnography or hypnology (Table III): electrophysiology of brain, heart, muscles an retina, respiration, pulsed oxymetry, movements of whole body, sleep architecture, central and peripheral apneas.

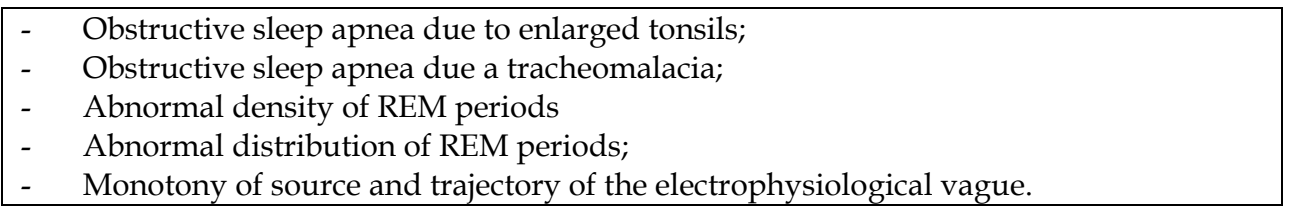

In our experience of sleep analysis in children having a ASD diagnosis, the interesting observation is concerning the analysis of brain electrogenesis: in its emergence, its distribution and progression in the different cortical areas.

We found a combination of:

- A repetitive emergence of electrogenesis in the the left hemisphere (and more precisely around junction of frontal and temporal lobes) and

- A monotony and the spreading of that electrogenesis in the other cortical areas. (see Figure 2).

One possible hypothesis is that the observed abnormalities in wake time can be earlier observed in sleeping time. The loss of a normal variability in the usual neurological and behavioural moments in daily life could reflect a sort of (brain) internal self defensive attitude, an over and repetitive use of the same (being considered as safe and comfortable) circuitries among neurological pathways. This could lead to a sort of physical and emotional dependency, to a real fatigue of finally to much devoted cognitive and associated motor areas.

Together to these overuse and also underuse of brain areas, the concerned neurotransmitters are also overused or underused. 
This could explain the following items in a strategy of self defense:

- the overfocusing areas of interest

- $\quad$ some periods of fatigue with suddenly an aggressive person against himself or an other person

- without the eventually need of adequacy on the moment of life

- without the need of waiting for or concerning the other

- without the need of integrating the task in the activities of a group

- without the approbation or interrogation (by listening to or looking at the other) in a task, or the use of a material.

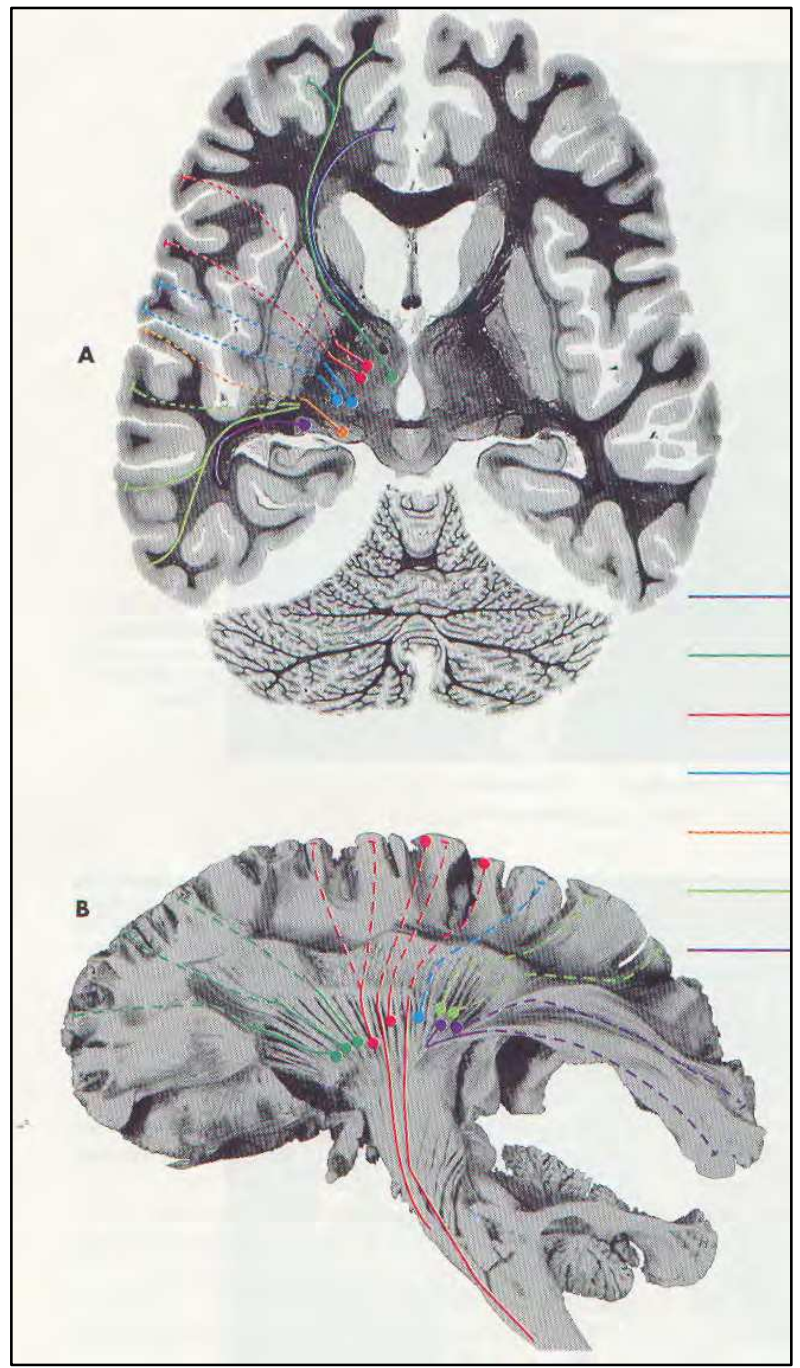

Fig. 2. Hypothetic fiber tracts repetitive activity in the autistic spectrum. 


\section{Integration of observation during sleeping and wake time for interventions and medications}

As others, we find an association between sleep analysis and daytime functioning in ASD. Although it is difficult in this type of pathology, to determine whether poor sleep is the cause or result of a more problematic daytime functioning, or whether the severity is contributing to both poor sleep and more impaired daytime functioning, it seems plausible to imagine, as what can be seen in patients not having an ASD, that a better sleep time will contribute to a better daytime functioning and vice versa, and the more that is maintained over time, the more the resistance to possible perturbing factors will be high or low.

Autism therapies are designed to treat symptoms (mood instability, sleep disorder, agressivity) or interrupt the abnormal equilibrium when this is found (disturbed balance of neurotransmitters, disturbed brain input of tryptophan or folinic acid, disturbed pineal secretion of melatonin, disturbed endorphin secretion against neuropathic pain.

\section{Behavioral and educational interventions}

The therapies have the following nominations: the antecedent package, the behavioral package, the comprehensive behavioral treatment, the join attention intervention, the modeling, the naturalistic teaching strategies, the peer training package, the pivotal response treatment schedules, the schedules, the self-management, the story-based intervention package. Their goals are to improve the social functioning (decrease non functional or negative behaviors), to move the child toward independence (better communication, more adaptive skills, promote academic functioning and cognition).

These combined and adapted therapies to the given precise case should begin as soon as possible, with a minimum 25 hours/week schedule, 12 months per year

\section{Medications}

They should be associated to the behavioral, educational and environmental interventions.

Usually, the medications are given either to treat symptoms or to reestablish a normal brain input of mediators.

These are:

- psychotropic therapies targeting (as antagonists) dopaminergic and or serotoninergic receptors: haloperidol, risperidone, clomipramide.

- Anxiolytic when the patient is particularly anxious

- $\quad$ Mood stabilizers

- Vitamins (folinic acid, B6, B12)

- tryptophan

- Opiods antagonists (naltrexone)

- Sleep concerns medications.

It is interesting to remind here the neurobiology or chemistry of sleep.

Sleep and ASD have similar neurotransmitters intervening in the sleep-wake cycle: GABA, serotonin, histamine, melatonin. For all these 4 molecules, abnormalities are found in ASD Any case is particular and request a fine analysis of daytime, sequence at bedtime, sleep time, but insomnia in ASD is particularly frequent. 
After having discarded other causes (gastro-oesophageal reflux, severe atopic dermatitis, cow's proteins or other allergy, tracheomalacia, enlarged tonsils or adenoids), we can choose the best or most appropriate medication. In this point of view, melatonin, then a benzodiazepine, then an antihistamine drug given 1 hour before bedtime beside other therapies in daytime, could counteract the disturbed balance of neurotransmitter.

\section{References}

[1] Symons FJ, Byiers BJ, Raspa M, Bishop E, Bailey DB. Self-injurious behavior and fragile $x$ syndrome: findings from the national fragile x survey. Am J Intellect Dev Disabil. 2010 Nov;115(6):473-81.

[2] Williams SR, Aldred MA, Der Kaloustian VM, Halal F, Gowans G, McLeod DR, Zondag S, Toriello HV, Magenis RE, Elsea SH. Haploinsufficiency of HDAC4 causes brachydactyly mental retardation syndrome, with brachydactyly type E, developmental delays, and behavioral problems. Am J Hum Genet. 2010 Aug 13;87(2):219-28. PubMed PMID: 20691407.

[3] Deonna T, Roulet-Perez E. Early-onset acquired epileptic aphasia (Landau-Kleffner syndrome, LKS) and regressive autistic disorders with epileptic EEG abnormalities: the continuing debate. Brain Dev. 2010 Oct;32(9):746-52. Epub 2010 Jul 15.

[4] Gillberg C. The ESSENCE in child psychiatry: Early Symptomatic Syndromes Eliciting Neurodevelopmental Clinical Examinations. Res Dev Disabil. 2010 NovDec;31(6):1543-51. Epub 2010 Jul 14.

[5] Cortesi F, Giannotti F, Ivanenko A, Johnson K. Sleep in children with autistic spectrum disorder. Sleep Med. 2010 Aug;11(7):659-64. Epub 2010 Jul 4. Review.

[6] Wright B, Sims D, Smart S, Alwazeer A, Alderson-Day B, Allgar V, Whitton C, Tomlinson H, Bennett S, Jardine J, McCaffrey N, Leyland C, Jakeman C, Miles J. Melatonin Versus Placebo in Children with Autism Spectrum Conditions and Severe Sleep Problems Not Amenable to Behaviour Management Strategies: A Randomised Controlled Crossover Trial. J Autism Dev Disord. 2010 Jun 10. [Epub ahead of print]

[7] Stevens L, Tartaglia N, Hagerman R, Riley K. Clinical report: a male with Down syndrome, fragile X syndrome, and autism. J Dev Behav Pediatr. 2010 May;31(4):333-7.

[8] Miano S, Ferri R. Epidemiology and management of insomnia in children with autistic spectrum disorders. Paediatr Drugs. 2010 Apr 1;12(2):75-84.

[9] Carbone PS, Farley M, Davis T. Primary care for children with autism. Am Fam Physician. 2010 Feb 15;81(4):453-60.

[10] Coury D. Medical treatment of autism spectrum disorders. Curr Opin Neurol. 2010 Apr;23(2):131-6.

[11] Sung M, Fung DS, Cai Y, Ooi YP. Pharmacological management in children and adolescents with pervasive developmental disorder. Aust N Z J Psychiatry. 2010 May;44(5):410-28.

[12] Ekinci O, Arman AR, IÅŸik U, Bez Y, Berkem M. EEG abnormalities and epilepsy in autistic spectrum disorders: clinical and familial correlates. Epilepsy Behav. 2010 Feb;17(2):178-82. Epub 2009 Dec 29. 
[13] Souders MC, Mason TB, Valladares O, Bucan M, Levy SE, Mandell DS, Weaver TE, Pinto-Martin J. Sleep behaviors and sleep quality in children with autism spectrum disorders. Sleep. 2009 Dec 1;32(12):1566-78.

[14] Wirojanan J, Jacquemont S, Diaz R, Bacalman S, Anders TF, Hagerman RJ, GoodlinJones BL. The efficacy of melatonin for sleep problems in children with autism, fragile X syndrome, or autism and fragile X syndrome. J Clin Sleep Med. 2009 Apr 15;5(2):145-50. Erratum in: J Clin Sleep Med. 2010 Aug 15;6(4):preceding 311. .

[15] Glickman G. Circadian rhythms and sleep in children with autism. Neurosci Biobehav Rev. 2010 Apr;34(5):755-68. Epub 2009 Dec 4. Review.

[16] Hughes JR. Update on autism: a review of 1300 reports published in 2008. Epilepsy Behav. 2009 Dec;16(4):569-89. Epub 2009 Nov 6. Review.

[17] Johnson KP, Giannotti F, Cortesi F. Sleep patterns in autism spectrum disorders. Child Adolesc Psychiatr Clin N Am. 2009 Oct;18(4):917-28. Review.

[18] Badoe EV. Classical Rett Syndrome in a Ghanaian child: a case report. West Afr J Med. 2009 Mar;28(2):134-6.

[19] Coury D, Jones NE, Klatka K, Winklosky B, Perrin JM. Healthcare for children with autism: the Autism Treatment Network. Curr Opin Pediatr. 2009 Dec;21(6):828-32. Review.

[20] Silva LM, Schalock M, Ayres R, Bunse C, Budden S. Qigong massage treatment for sensory and self-regulation problems in young children with autism: a randomized controlled trial. Am J Occup Ther. 2009 Jul-Aug;63(4):423-32. 


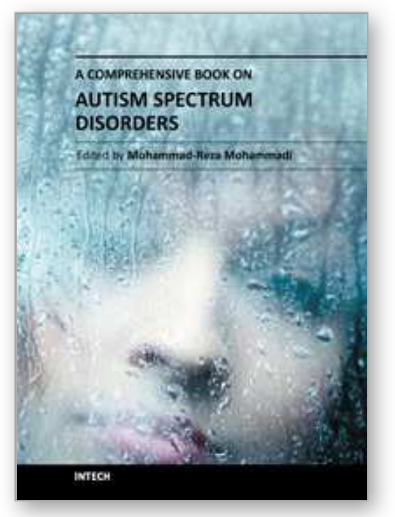

\section{A Comprehensive Book on Autism Spectrum Disorders}

Edited by Dr. Mohammad-Reza Mohammadi

ISBN 978-953-307-494-8

Hard cover, 478 pages

Publisher InTech

Published online 15, September, 2011

Published in print edition September, 2011

The aim of the book is to serve for clinical, practical, basic and scholarly practices. In twentyfive chapters it covers the most important topics related to Autism Spectrum Disorders in the efficient way and aims to be useful for health professionals in training or clinicians seeking an update. Different people with autism can have very different symptoms.Â Autism is considered to be a â€œspectrumâ€ disorder, a group of disorders with similar features. Some people may experience merely mild disturbances, while the others have very serious symptoms. This book is aimed to be used as a textbook for child and adolescent psychiatry fellowship training and will serve as a reference for practicing psychologists, child and adolescent psychiatrists, general psychiatrists, pediatricians, child neurologists, nurses, social workers and family physicians. A free access to the full-text electronic version of the book via Intech reading platform at http://www.intechweb.org is a great bonus.

\section{How to reference}

In order to correctly reference this scholarly work, feel free to copy and paste the following:

Oreste Battisti (2011). Sleep Concerns and Disorders in Children with an Autistic Spectrum Disorder (ASD), A Comprehensive Book on Autism Spectrum Disorders, Dr. Mohammad-Reza Mohammadi (Ed.), ISBN: 978953-307-494-8, InTech, Available from: http://www.intechopen.com/books/a-comprehensive-book-on-autismspectrum-disorders/sleep-concerns-and-disorders-in-children-with-an-autistic-spectrum-disorder-asd-

\section{INTECH}

open science | open minds

\section{InTech Europe}

University Campus STeP Ri

Slavka Krautzeka 83/A

51000 Rijeka, Croatia

Phone: +385 (51) 770447

Fax: +385 (51) 686166

www.intechopen.com

\section{InTech China}

Unit 405, Office Block, Hotel Equatorial Shanghai

No.65, Yan An Road (West), Shanghai, 200040, China

中国上海市延安西路65号上海国际贵都大饭店办公楼 405 单元

Phone: +86-21-62489820

Fax: $+86-21-62489821$ 
(C) 2011 The Author(s). Licensee IntechOpen. This chapter is distributed under the terms of the Creative Commons Attribution-NonCommercialShareAlike-3.0 License, which permits use, distribution and reproduction for non-commercial purposes, provided the original is properly cited and derivative works building on this content are distributed under the same license. 